\title{
Thermal effects of the Santa Eulália Plutonic Complex (southern Portugal) on the meta-igneous and metasedimentary host rocks
}

\section{Los efectos térmicos del Complejo Plutónico de Santa Eulalia (sur de Portugal) en las rocas metaígneas y metasedimentarias encajantes}

\author{
C. Cruz¹, M.A. Ribeiro'1, H. Sant'Ovaia'1, H.C.B. Martins ${ }^{1}$ \\ 1 Geology Centre from Porto University, Department of Geosciences, Environment and Spatial Planning, Faculty of Sciences \\ of Porto University, Rua do Campo Alegre, 4169-007 Porto, Portugal. Email: claudiacfcruz@gmail.com
}

\begin{abstract}
The Santa Eulália Plutonic Complex (SEPC) is a late-Variscan granitic body located in the northern part of the Ossa Morena Zone, a inner zone of the Variscan Iberian Massif. The SEPC host rocks are composed of metaigneous and metasedimentary units, from Upper Proterozoic to Paleozoic ages, with a NW-SE structure, cross-cut by the SEPC. The SEPC host rocks, with low grade metamorphism show well preserved primary sedimentary or igneous mineralogical, textural and structural features. The thermal effect induced by the SEPC is restricted to the roof pendants. At $\mathrm{N}$ and NE of the SEPC, textures and paragenesis resulting from thermal metamorphism, are not related to the SEPC intrusion but to a previous magmatism, controlled by the NW-SE regional anisotropies.

The restriction of the thermal effects to the pluton roof may be caused by a combination of several interrelated factors: higher volume of granitic mass, thermal effect by advection of fluids and longer period of prevalence of high thermal conditions.

The geochemical study of SEPC host rocks shows the heterogeneous character and diversity of metasedimentary, igneous and meta-igneous rocks. The whole rock geochemical data indicate that all the metasedimentary lithologies derived from an upper continental crustal source and the igneous and meta-igneous rocks show no evidence of metasomatic effects by the SEPC emplacement.
\end{abstract}

Keywords: Thermal effects; meta-igneous rocks; metasedimentary rocks; petrography; geochemistry

\section{RESUMEN}

El Complejo Plutónico de Santa Eulalia (CPSE) es un cuerpo granítico tardi-Varisco situado en la parte norte de la Zona de Ossa Morena, en la zona interior del Macizo Ibérico Varisco. Las rocas encajantes del CPSE están compuestas por unidades meta-ígneas y metasedimentarias, de edades que van desde el Proterozoico Superior hasta el Paleozoico, con una estructura de dirección NW-SE, cortada por el CPSE. Las rocas encanjantes del CPSE, con metamorfismo de bajo grado conservan estructuras, mineralogía y textura primarias. El efecto térmico

Recibido el 1 de abril de 2014 / Aceptado el 3 de noviembre de 2014 / Publicado el 1 de diciembre de 2014

Citation / Cómo citar este artículo: C. Cruz et al. (2014). Thermal effects of the Santa Eulália Plutonic Complex (southern Portugal) on the meta-igneous and metasedimentary host rocks. Estudios Geológicos 70(2): e016. http://dx.doi.org/10.3989/egeol.41730.322.

Copyright: (c) 2014 CSIC. This is an open-access article distributed under the terms of the Creative Commons Attribution-Non Commercial (by-nc) Spain 3.0 License. 
inducido por el CPSE se limita a los roof pendants. AI N y NE del CPSE, las texturas y paragénesis resultantes del metamorfismo térmico, no están relacionadas con la intrusión del CPSE sino con un magmatismo anterior, controlado por anisotropías regionales NW- SE.

La restricción de los efectos térmicos al techo del pluton puede ser causada por una combinación de varios factores interrelacionados: mayor volumen de masa granítica, un efecto térmico por la advección de fluidos y el período de prevalencia de altas condiciones térmicas.

Los datos geoquímicos de las rocas encanjantes del CPSE muestran el carácter heterogéneo y la diversidad de rocas sedimentarias, metasedimentarias, ígneas y meta-ígneas. El análisis de los datos geoquímicos indica que todas las litologías sedimentarias y metasedimentarias han derivado de la corteza continental superior, mientras las rocas ígneas y meta-ígneas tienen una composición que no muestra evidencias de efectos metasomáticos por el emplazamiento del CPSE.

Palabras clave: Efectos térmicos; rocas metaígneas; rocas metasedimentarias; petrografía; geoquímica

\section{Introduction}

The Ossa Morena Zone (OMZ) is one of the inner zones of the Variscan Iberian Massif, which is considered to be accreted to the Iberian Autochthonous terrane during the Cadomian cycle (Ribeiro et al., 2010). To the north, the OMZ is limited by the Coimbra-Cordoba Shear Zone (CCSZ), considered as a Cadomian suture, reactivated as a Variscan structure. To the south, the suture between the OMZ and the South Portuguese Terrane (SPT) corresponds to the SW-Iberia Variscan suture (Quesada et al., 1994; Fonseca et al., 1999; Ribeiro et al., 2010).

The OMZ is characterized by a poliphase ductile deformation and metamorphism. Two or three Variscan phases are recognizable at OMZ. $\mathrm{D}_{1}$ structures display WNW-ESE strike and have around $370 \mathrm{Ma}$ in age; $\mathrm{D}_{2}$ phase is characterized by the development of N-S or NNW-SSE folding and shear; finally, $\mathrm{D}_{3}$ structures display a NW-SE trend and are dated at $306 \mathrm{Ma}$ (Moita et al., 2005; Ribeiro et al., 2007). The regional structure in the OMZ has a NW-SE orientation.

In the portuguese part of the OMZ several sectors with distinct stratigraphy and structure are identified by Oliveira et al. (1991). From the north to the south the following sectors are recognized: (i) Blastomilonitic Belt, (ii) Alter do Chão-Elvas, (iii) Estremoz-Barrancos, (iv) Montemor-Ficalho and (v) Beja Massif. This study will cover: Blastomilonitic Belt, also known as the Coimbra-Cordoba Shear Zone (CCSZ) and the CCSZ southern margin (Pereira et al., 2013), the Alter do Chão-Elvas sector and although with less detail, the Estremoz-Barrancos sector (Araújo et al., 2013; Fig. 1).

The Santa Eulália Plutonic Complex (SEPC) is a late-Variscan granitic pluton in the SW sector of the Iberian Orogen. This granite with $400 \mathrm{~km}^{2}$ cross-cuts the regional NW-SE Variscan structures, namely a major high-grade and high-strain shear zone in the contact between two axial geotectonic zones of the Iberian Variscan Belt: Central Iberian Zone (CIZ) and Ossa Morena Zone (OMZ).

In the published geological map (Gonçalves, 1972, 1975) a regular metamorphic thermal aureole (1.5 to $2 \mathrm{~km})$ surrounding the SEPC is represented. However, the present study highlights the absence of thermal effects in surrounding rocks, except in the roof pendants.

In this study the evaluation of the thermal effects promoted by the SEPC intrusion are presented as a part of a multidisciplinary study. This evaluation is supported mainly by petrographic study, complemented by lithogeochemical data.

\section{Geological setting}

The SEPC is a ring igneous complex composed, from the rim to the core, of a medium- to coarsegrained pink granite ( $\mathrm{G} 0$-group), involving large (kilometric) elongated masses of mafic (gabbroic) to intermediate (granodioritic) rocks, and a central gray medium-grained granite (G1-group) typically biotitic, sometimes showing a slight porphyritic tendency, namely in a few outcrops located near the contact with the peripheral G0-type ring (Lopes et al., 1997, 1998; Menéndez et al., 2006).

The SEPC host rocks show lithological diversity and are composed of igneous and meta-igneous and metasedimentary units, from Upper Proterozoic to Lower Paleozoic ages (Table 1).

The lithostratigraphic units, as well as the major thrust are represented in fig. 1. The area surrounding the SEPC is characterized by a Variscan senestral tectonic regime, which is marked by the NW-SE 


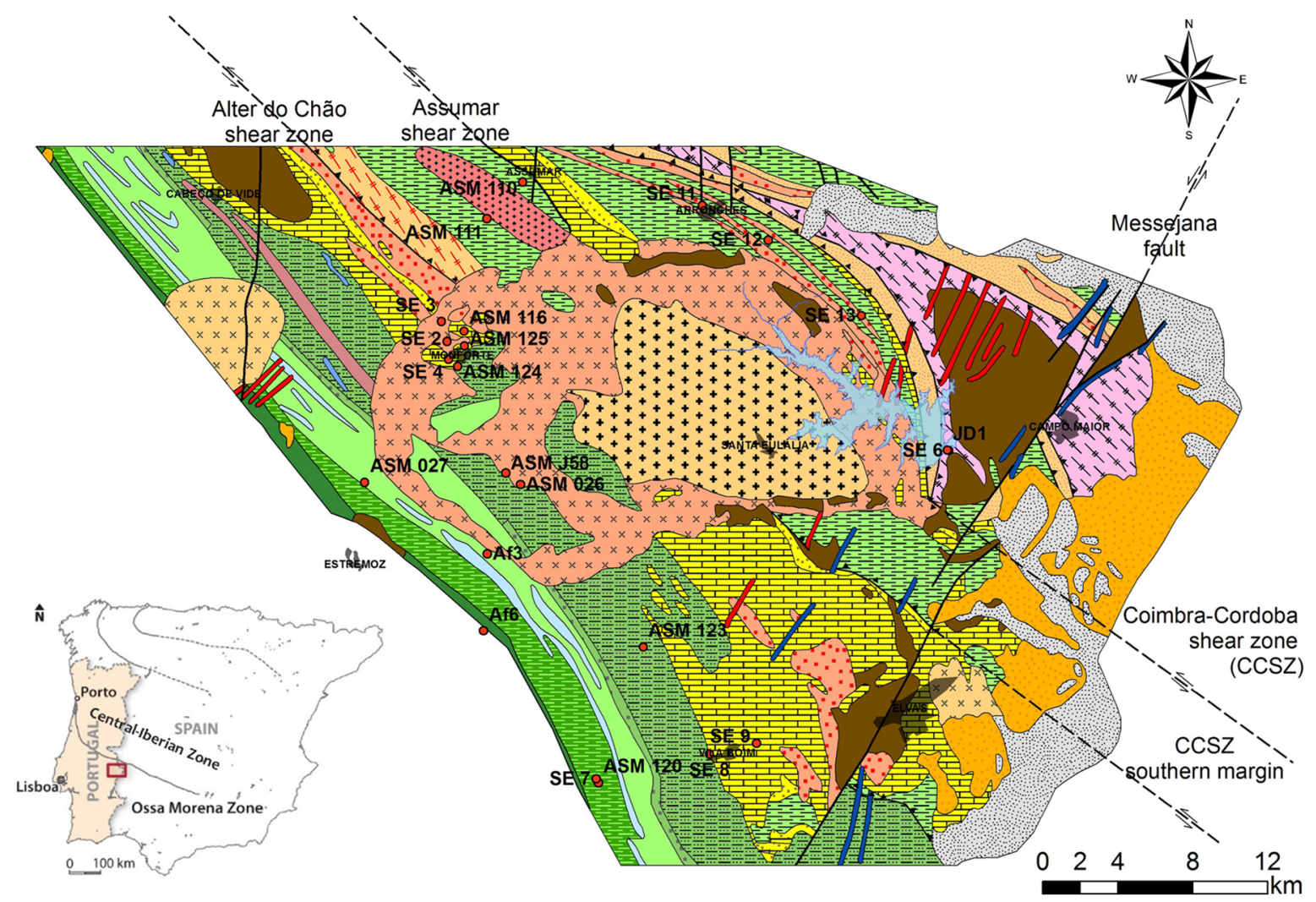

\section{Geology:}

QUATERNARY

Terrace and sands

NEOGENE

$\square$ Vale do Guizo Formation: conglomerates, sands, arcoses and carbonates ORDOVICIAN

$\square$ Barrancos Formation: schists and psammites

CAMBRIAN

Fatuquedo Formation: schists, greywackes, arenites and conglomerates

$\square$ Terrugem Volcanic-Sedimentary Complex: schists and arenites/greywackes

$\square$ Terrugem Volcanic-Sedimentary Complex: basic volcanites

$\square$ Vila Boim Formation: quartzitic conglomerate - Barra quartzitica

Vila Boim Formation: schists and arenites

$\square$ Vila Boim Formation: acids volcanites

$\square$ Vila Boim Formation: basic volcanites

도 Limestones and marbles (Carbonate Formation)

$\therefore$ Conglomerates and acid volcanites - Early Cambrian

PROTEROZOIC

Mosteiros Formation (Série Negra): schists, greywackes,
black chertes, amphibolites
$\square$ Morenos Formation: metarenites with acids volcanites
$\square$ Campo Maior Formation: gneiss and migmatites

LATE-VARISCAN GRANITES

Two-mica granite - Barquete granite

Biotite granite - G0 facies

$\because:$ P Porphyritic biotite granite - G1 facies

$[x]$ Others biotite granite

BASIC AND ULTRABASIC ROCKS

$\square$ Gabbros, diorites and peridotites

PRE-VARISCAN ROCKS

Peralkaline rocks

$\square$ Orthogneiss

FILONIAN ROCKS

Ryolite porphyry, granite porphyry and aplite-pegmatite

Dolerite dike of Alentejo and other basic rocks

\section{Legend:}

- $\quad$ Sampling sites

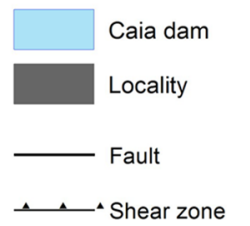

Fig. 1.-Geological map of the SEPC and host rocks with sampling sites location (adapted from Oliveira et al., 1992; Araújo et al., 2013 and Pereira et al., 2013). 
Table 1.-Sampling for petrographic and geochemical study.

\begin{tabular}{|c|c|c|c|}
\hline & Sample & Unit & Lithology \\
\hline \multirow[t]{21}{*}{ Metasedimentary units } & SE 4 & Carbonate Formation & Carbonate rock \\
\hline & SE $6 a$ & Série Negra & Siliciclastic rock \\
\hline & SE $6 b$ & Carbonate Formation & Dolomitic limestone \\
\hline & SE $6 c$ & Carbonate Formation & Marble \\
\hline & SE 7 & Terrugem Volcanic-sedimentary Complex & Pelitic rock \\
\hline & SE $8 a$ & Vila Boim Formation & Pelitic rock \\
\hline & SE $8 b$ & Vila Boim Formation & Pelitic rock \\
\hline & SE 8c & Vila Boim Formation & Pelitic rock \\
\hline & SE 9b & Carbonate Formation & Carbonate rock \\
\hline & ASM 026 & Vila Boim Formation & Pelitic rock \\
\hline & ASM 027 & Terrugem Volcanic-sedimentary Complex & Quartz-pelitic rock \\
\hline & ASM 110 & Série Negra & Pelitic rock \\
\hline & ASM 111 & Série Negra & Amphibolite \\
\hline & ASM 116 & Vila Boim Formation & Pelitic rock \\
\hline & ASM 123 & Vila Boim Formation & Quartz-pelitic rock \\
\hline & ASM 124 & Carbonate Formation & Carbonate rock \\
\hline & ASM 125 & Série Negra & Pelitic rock \\
\hline & ASM J58 & Vila Boim Formation & Pelitic rock \\
\hline & Af 3 & Terrugem Volcanic-sedimentary Complex & Quartz-pelitic rock \\
\hline & Af 6 & Barrancos Formation & Quartz-pelitic rock \\
\hline & JD1 & Carbonate Formation & Marble \\
\hline \multirow[t]{8}{*}{ Meta-igneous units } & SE 2 & Vila Boim Formation & Basic volcanic rock \\
\hline & SE 11 & Pre-Variscan peralkaline rock & Alkaline rock \\
\hline & SE 9a & Carbonate Formation & Basic rock \\
\hline & SE 9c & Carbonate Formation & Acid rock \\
\hline & SE 9d & Carbonate Formation & Basic rock \\
\hline & SE $12 a$ & Série Negra & Amphibolite \\
\hline & SE $12 b$ & Pre-Variscan peralkaline rock & Alkaline rock \\
\hline & SE 13 & Pre-Variscan peralkaline rock & Metasomatized alkaline rock \\
\hline
\end{tabular}

shear zone, namely the Coimbra-Cordoba Shear Zone (CCSZ) and the Alter do Chão shear zone (Fig.1). The SEPC is limited to NE by the CCSZ and to SW by the Juromenha vertical thrust (Araújo et al., 2013). To the east the SEPC is limited by a major NNE-SSW tectonic structure, the Messejana fault. This fault had a complex tectonic history, from a late Variscan time with left lateral strike-slip fault, to a transtensional fault in Triassic-Jurassic time (Schermerhorn et al., 1978).

It should be noted that the roof pendants consist of lithological fragments of host rocks, located at the roof of the granitic body. These fragments preserve the regional structure of the surrounding rocks. The roof pendants of the SEPC have cartographic expression, namely in the western sector of the granitic massif, in G0 facies, at SW of the Alter do Chão shear zone (Fig.1).

\section{The meta-igneous and metasedimentary host rocks}

The SEPC host rocks are composed of low to highgrade metamorphic rocks. In the NE-sector of Alter do Chão shear zone two lithostratigraphic units are present: a low grade metasedimentary Ediacaran unit 
(Série Negra) composed of siliciclastic rocks, including black cherts (sample SE 6a), and the Carbonate Formation including impure marble (samples SE 6c and JD1) and dolomite limestone (sample SE 6b). These low grade units are adjacent to high grade unit with alkaline rocks (samples SE 11, SE 12b), metasomatized alkaline rocks (SE 13) and migmatites. In this high-grade zone, deformed pelitic (sample ASM 110) and amphibolite (sample ASM 111) rocks are also observed.

In the SW sector of the Alter do Chão shear zone, a low-grade metasedimentary and metavolcanic Cambrian sequence is composed of quartz-pelitic (samples ASM 027, ASM 123, Af 3 and Af 6), basic (sample SE 9a), carbonate (sample SE 9b) and acid (sample SE 9c) rocks. The roof pendants lithologies are composed of pelitic (samples ASM 026, ASM 116, ASM 125 and ASM J58), carbonate (samples ASM 124 and SE 4) and volcanic rocks (sample SE 2).

The lithostratigraphic units are bounded by major high-strain transcurrent faults placing side by side different rock types and different metamorphic grades. All these units show a regional vertical structure (Fig. 1).

\section{Petrography of host rocks}

The petrographic study was based on 18 sampling sites (Fig. 1), located in the surrounding host rocks and in the roof pendants. On these samples 23 thin sections for detailed petrographic analysis have been studied.

On the ESE margin of the SEPC, the pelitic rocks of the Série Negra present anisotropies, which are marked by a compositional sedimentary bedding. The sample SE 6a (phyllite), which is close to the ESE of the SEPC, has a granolepidoblastic texture with a quartz-moscovite matrix and post-kinematic small biotite crystals transverse or mimetic, over the foliation (Fig. 2a). These phyllites intercalated with quartz-phyllites show mineralogy and texture pointing to the transition from chlorite to biotite zone.

On the northern margin of the SEPC, quartz-pelitic rocks of the Série Negra (sample ASM 110), adjacent to the Assumar shear zone and to the Barquete granite, $526 \mathrm{Ma}$ in age (Pereira et al., 2011) show heterogranular granoblastic polygonal texture with deformation lamellae and quartz ribbons typical of dinamothermal metamorphism prior to the intrusion of the SEPC (Fig. 2b).

Metasomatized alkaline rocks, adjacent to the NE contact of the SEPC (sample SE 13) present homogeneous texture with a banded structure preserved. The mineralogy of these rocks is composed of clinopyroxene, scapolite, riebeckite, epidote, perthite potassium feldspar, plagioclase and opaque minerals (Fig. 2c). Their spatial association with ordovician alkaline rocks (Gonçalves, 1971) intrusive in metassedimentary sequence (Série Negra and Carbonate Formation) with NW-SE trending, explain the mineralogy, namely the presence of the Na-amphibole. The compositional banding, the texture and the mineral composition of these rocks (Table 2), with Na-amphiboles suggest that they have resulted from thermal/metasomatic effects of alkaline intrusion over the adjacent carbonate rocks.

Carbonate Formation samples, even when located a few meters from the SEPC, do not show recrystallization due to thermal contact. These samples are impure carbonate rocks and heterogranular calcsilicate rocks, with primary mineralogical and textural features still preserved, namely detrital micas and granular variations which mark the stratification $\left(\mathrm{S}_{0}\right)$. These features are not observed in the samples of the same unit when located in roof pendants (sample SE 4) where the texture is strongly poligonized and the mineralogical composition is calcite, vesuvianite, tremolite, epidote and opaques (Fig. 2d).

The siliciclastic and the volcanic rocks, both of the Vila Boim Formation and of the Terrugem Volcanic-sedimentary Complex, outcropping at SW of the Alter do Chão shear zone, present metamorphic thermal effects only in the roof pendants. At roof of the SEPC the basic volcanic rock are amphibolitized and the siliciclastic rocks show paragenesis with fibrolite, polygonal quartz, calcite, plagioclase, cordierite, andalusite and quartz "pool" involving the plagioclase with metamorphic texture. This kind of texture indicate partial melting process (Fig. 2e). In the surrounding host rocks, at the west of the SEPC, the phyllites of Terrugem Volcanic-sedimentary Complex (sample ASM 027) show micro-veins with granite affinity composition ( $2 \mathrm{~mm}$ thick) with biotite, quartz, 

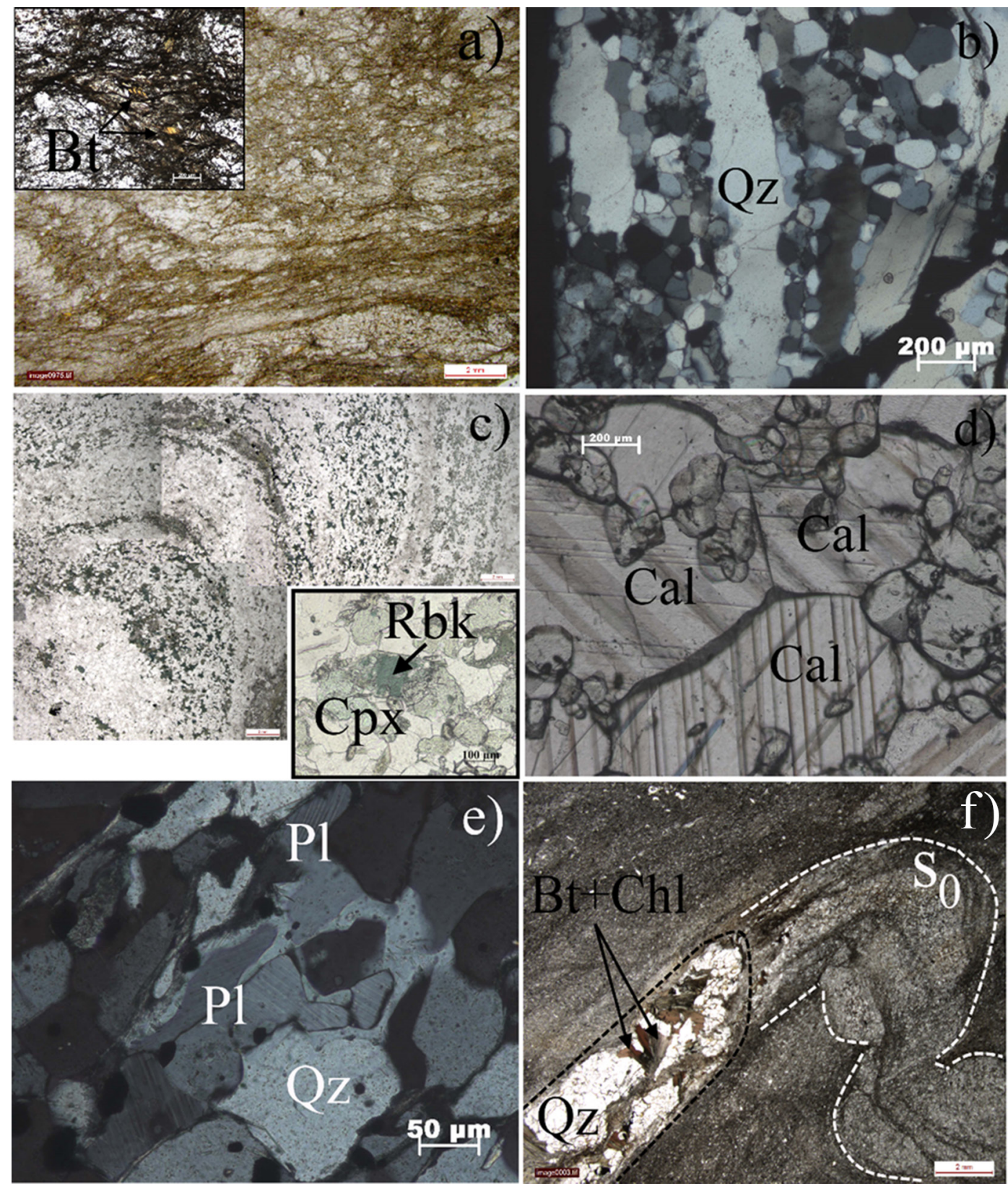

Fig. 2.-Photomicrographs of selected thin sections: a) Phyllite of Série Negra (sample SE 6a); b) Quartz ribbons in quartz-pelitic rock of Série Negra (ASM 110); c) Metasomatized alkaline rock (SE 13) with deformed composition banding; d) Roof pendant marble of Carbonate Formation with calcite poligonization (SE 4); e) Roof pendant pelitic rock with "pool" of quartz involving plagioclase (ASM 116); f) Quartz-pelitic rock with micro-vein (ASM 027).

chlorite and apatite. These veins are parallel to the rock structure, marked by stratification and foliation $\left(\mathrm{S}_{0} / / \mathrm{S}_{\mathrm{n}}\right)$. Neither blastese effects or mineralogical modification were observed in the phyllites adjacent to the veins (Fig. 2f). In phyllites the quartz grains show clastic textures with heterogeneous shape and size.

\section{Geochemistry}

The geochemical composition of the host rocks shows very well the diversity of metasedimentary and meta-igneous lithologies (Table 2). The samples studied include basic volcanic (sample SE 2) and pelitic rocks (samples SE 8a, SE 8b) of the Vila 
Table 2.-Whole rock major and minor (\%) and trace (ppm) elements composition of the SEPC host rocks.

\begin{tabular}{|c|c|c|c|c|c|c|c|c|c|c|c|c|c|c|}
\hline & SE 2 & SE 4 & SE 7 & SE 8a & SE 8b & SE 8c & SE 9a & SE 9b & SE 9c & SE 9d & SE 11 & SE 12a & SE 12b & SE 13 \\
\hline $\begin{array}{l}\text { Type } \\
\text { of rock }\end{array}$ & Basic & Carbonate & Pelitic & Pelitic & Pelitic & Pelitic & Basic & Carbonate & Acid & Basic & Alkaline & $\begin{array}{l}\text { Amphi- } \\
\text { bolite }\end{array}$ & Alkaline & $\begin{array}{l}\text { Metaso- } \\
\text { matized } \\
\text { alkaline }\end{array}$ \\
\hline $\mathrm{SiO}_{2}$ & 57.6 & 10.2 & 60.1 & 60.4 & 72.9 & 81.34 & 46.8 & 17.0 & 74.7 & 48.5 & 61.3 & 49.8 & 60.5 & 33.9 \\
\hline $\mathrm{Al}_{2} \mathrm{O}_{3}$ & 15.9 & 1.9 & 17.9 & 18.3 & 14.2 & 9.36 & 15.9 & 3.4 & 13.2 & 16.5 & 18.2 & 15.4 & 16.7 & 10.0 \\
\hline $\mathrm{Fe}_{2} \mathrm{O}_{3}$ & 5.41 & 0.85 & 6.59 & 6.46 & 3.07 & 2.8 & 8.85 & 1.89 & 1.02 & 9.98 & 4.93 & 11.7 & 6.16 & 3.6 \\
\hline MnO & 0.05 & 0.03 & 0.09 & 0.01 & 0.01 & 0.006 & 0.04 & 0.07 & 0.03 & 0.03 & 0.13 & 0.18 & 0.23 & 0.09 \\
\hline $\mathrm{MgO}$ & 3.49 & 1.54 & 2.12 & 1.77 & 0.08 & 0.04 & 4.94 & 15.8 & 0.30 & 5.10 & 0.28 & 6.09 & 0.39 & 2.37 \\
\hline $\mathrm{CaO}$ & 5.02 & 48.1 & 0.81 & 0.39 & 0.3 & 0.13 & 5.19 & 23.2 & 0.55 & 4.05 & 1.27 & 11.9 & 3.49 & 28.7 \\
\hline $\mathrm{Na}_{2} \mathrm{O}$ & 7.24 & 0.17 & 0.75 & 1.89 & 7.97 & 5.27 & 4.99 & 1.39 & 3.32 & 5.20 & 6.09 & 2.87 & 5.38 & 1.92 \\
\hline $\mathrm{K}_{2} \mathrm{O}$ & 0.45 & 0.75 & 3.97 & 4.58 & 0.24 & 0.11 & 0.72 & 0.31 & 4.71 & 0.16 & 6.08 & 0.44 & 5.41 & 1.95 \\
\hline $\mathrm{TiO}_{2}$ & 2.19 & 0.08 & 0.86 & 0.82 & 0.65 & 0.42 & 2.85 & 0.15 & 0.02 & 2.95 & 0.35 & 1.59 & 0.46 & 0.54 \\
\hline $\mathrm{P}_{2} \mathrm{O}_{5}$ & 0.81 & 0.03 & 0.11 & 0.20 & 0.15 & 0.07 & 0.79 & 0.05 & $<0.01$ & 0.83 & 0.10 & 0.17 & 0.11 & 0.16 \\
\hline LOI & 0.56 & 35.47 & 5.24 & 4.03 & 0.39 & 0.53 & 7.89 & 33.19 & 1.59 & 7.17 & 0.67 & 0.69 & 0.62 & 15.64 \\
\hline Total & 98.67 & 99.1 & 98.52 & 98.86 & 99.98 & 100.1 & 99.01 & 96.46 & 99.35 & 100.4 & 99.39 & 100.9 & 99.46 & 98.91 \\
\hline $\mathrm{Ba}$ & 66 & 273 & 855 & 295 & 51 & 21 & 83 & 14 & 77 & 48 & 132 & 153 & 1807 & 314 \\
\hline $\mathrm{Sr}$ & 267 & 3042 & 60 & 58 & 111 & 60 & 908 & 61 & 47 & 998 & 101 & 233 & 145 & 2511 \\
\hline$Y$ & 64 & 3 & 29 & 27 & 20 & 18 & 33 & 6 & 18 & 32 & 13 & 32 & 16 & 17 \\
\hline $\mathrm{Zr}$ & 509 & 22 & 190 & 157 & 160 & 192 & 328 & 30 & 56 & 338 & 472 & 111 & 201 & 145 \\
\hline $\mathrm{Zn}$ & 30 & 30 & 110 & 30 & 30 & 30 & 480 & 30 & 30 & 30 & 70 & 100 & 120 & 50 \\
\hline $\mathbf{R b}$ & 23 & 2 & 28 & 25 & 15 & 2 & 30 & 5 & 23 & 31 & 22 & 18 & 23 & 13 \\
\hline $\mathrm{Nb}$ & 48.7 & 3.10 & 42.5 & 37.2 & 22.6 & 7 & 44.9 & 8.60 & 9.20 & 46.2 & 45.2 & 12.6 & 27.3 & 20.0 \\
\hline Cs & 0.5 & 1.3 & 7.2 & 3.3 & 0.5 & 0.5 & 0.8 & 0.5 & 4.8 & 0.5 & 2.0 & 0.5 & 1.0 & 2.8 \\
\hline La & 33.3 & 3.5 & 50.3 & 42.3 & 26.3 & 14.5 & 45.6 & 11.8 & 9.5 & 45 & 90.6 & 6.4 & 31.1 & 22.5 \\
\hline $\mathrm{Ce}$ & 78.8 & 7.1 & 100 & 87.9 & 55.7 & 31.9 & 93 & 22.5 & 19.4 & 93.9 & 155 & 15.9 & 58.2 & 44.8 \\
\hline $\mathrm{Pr}$ & 10.9 & 0.8 & 11.3 & 9.69 & 6.05 & 3.61 & 11.1 & 2.48 & 2.37 & 11.5 & 14.3 & 2.49 & 7.16 & 5.21 \\
\hline Nd & 48.7 & 3.1 & 42.5 & 37.2 & 22.6 & 14.5 & 44.9 & 8.6 & 9.2 & 46.2 & 45.2 & 12.6 & 27.3 & 20 \\
\hline $\mathrm{Sm}$ & 12.6 & 0.7 & 8 & 7.2 & 4.4 & 3 & 9.6 & 1.6 & 2.9 & 9.6 & 5.4 & 3.8 & 4.9 & 3.9 \\
\hline $\mathrm{Eu}$ & 3.54 & 0.12 & 1.49 & 1.59 & 0.92 & 0.65 & 2.94 & 0.36 & 0.24 & 2.98 & 1.25 & 1.49 & 2.85 & 0.85 \\
\hline Gd & 12.6 & 0.6 & 7 & 6.4 & 4 & 2.9 & 8.9 & 1.3 & 3.2 & 8.9 & 4.2 & 5.4 & 4.4 & 3.1 \\
\hline Tb & 2.2 & 0.1 & 1 & 1 & 0.6 & 0.5 & 1.2 & 0.2 & 0.5 & 1.2 & 0.5 & 0.9 & 0.5 & 0.5 \\
\hline Dy & 13 & 0.5 & 5.5 & 5.4 & 3.3 & 3.1 & 6.3 & 1.2 & 2.9 & 6.1 & 2.6 & 5.3 & 3.1 & 2.9 \\
\hline Ho & 2.7 & 0.1 & 1.1 & 1 & 0.7 & 0.6 & 1.1 & 0.2 & 0.5 & 1.1 & 0.5 & 1.1 & 0.6 & 0.6 \\
\hline $\mathrm{Er}$ & 7.4 & 0.3 & 3.1 & 3 & 2 & 0.26 & 3.1 & 0.6 & 1.6 & 3.1 & 1.5 & 3.1 & 1.5 & 1.7 \\
\hline $\mathrm{Tm}$ & 1.16 & 0.05 & 0.46 & 0.43 & 0.29 & 1.6 & 0.45 & 0.1 & 0.23 & 0.45 & 0.22 & 0.46 & 0.25 & 0.25 \\
\hline $\mathrm{Yb}$ & 7.4 & 0.3 & 3.1 & 2.9 & 2 & 0.26 & 2.8 & 0.6 & 1.5 & 2.8 & 1.7 & 2.9 & 1.7 & 1.6 \\
\hline Lu & 1.21 & 0.04 & 0.51 & 0.49 & 0.33 & 4.3 & 0.37 & 0.08 & 0.2 & 0.37 & 0.31 & 0.4 & 0.27 & 0.23 \\
\hline $\mathrm{Hf}$ & 12.5 & 0.5 & 5.2 & 4.2 & 4.1 & 0.5 & 6.9 & 0.7 & 2.8 & 7.1 & 8.4 & 2.7 & 4.7 & 3 \\
\hline $\mathrm{Ta}$ & 2 & 0.1 & 1.5 & 1 & 0.7 & 0.26 & 3.8 & 0.1 & 1.9 & 4 & 6.1 & 0.3 & 2.7 & 1.2 \\
\hline $\mathrm{Pb}$ & $<5$ & 5 & 24 & $<5$ & 5 & 5 & 5 & 5 & 53 & 5 & 10 & 5 & 26 & 5 \\
\hline $\mathrm{Bi}$ & $<0.4$ & 0.4 & 0.9 & 0.4 & 0.4 & 0.4 & 0.4 & 0.4 & 0.4 & 0.4 & 0.4 & 0.4 & 0.4 & 0.4 \\
\hline Th & 5.7 & 1.4 & 19.2 & 11.8 & 7.2 & 5.3 & 4.1 & 2.3 & 22.2 & 4.3 & 13.9 & 0.4 & 3.3 & 7.3 \\
\hline U & 2.4 & 1 & 2.7 & 2.5 & 1.4 & 1.2 & 1.6 & 0.9 & 10.3 & 1.5 & 3.1 & 0.3 & 0.9 & 2.5 \\
\hline
\end{tabular}


Boim Formation, carbonate (samples SE 4 and SE $9 \mathrm{~b}$ ) and meta-igneous rocks (basic rocks: samples SE 9a and SE 9d and acid rocks: sample SE 9c) intercalated or intrusive in the Carbonate Formation, pelitic rocks of Terrugem Volcanic-sedimentary Complex (sample SE 7), amphibolites (sample SE 12a) of the Série Negra and finally banded alkaline rocks (samples SE 11, SE 12b) and metasomatized alkaline rocks (SE 13) respectively intruded or intercalated in the Série Negra.

The Rare Earth Elements (REE) patterns were plotted in separeted graphs according to the sedimentary or igneous character of the samples (Fig. 3a and Fig. 3b).

The pelitic and carbonate metasedimentary rocks show a typical continental crust REE pattern with high LREE fractionation ( $\mathrm{La} / \mathrm{Sm}=1.06-10.56)$, marked negative Eu anomaly and low HREE fractionation $(\mathrm{Gd} / \mathrm{Yb}=1.38-2.57)$, but with different $\sum \mathrm{REE}$ values. The carbonate rocks show the lower values of $\sum$ REE, and the more pelitic rocks (samples SE 7 and SE 8a) show the highest values (Fig. 3a). The meta-igneous rocks present quite different REE patterns (Fig. 3b): the alkaline rocks have low or null Eu anomaly, a high fractionation of LREE and low fractionation of HREE. The basic rocks have a flat LREE and HREE patterns without Eu anomaly (samples SE 2 and SE 12a), and finally, the acid igneous rocks show a fairly steep LREE and flat HREE patterns.

\section{Thermal effects induced by the SEPC}

The lithological and metamorphic diversity of the host rocks imply different degrees of evidence for thermal effects of the SEPC. Undoubtedly the pelitic rocks and impure carbonate lithologies (limestones and dolomitic limestones) of low grade are the most favorable to constraint contact effects. It is much more difficult the discrimination of these effects on igneous rocks or high grade metamorphic rocks.

In the pelitic and impure carbonate lithologies surrounding the SEPC, the mineralogical, textural and structural features of the very-low to low grade metamorphic conditions previous to the SEPC intrusion are preserved, namely the sedimentary bedding. The thermal effects of this intrusion are expressed only by very small post-kinematic crystals of biotite, transverse or mimetic, over the foliation in the pelitic
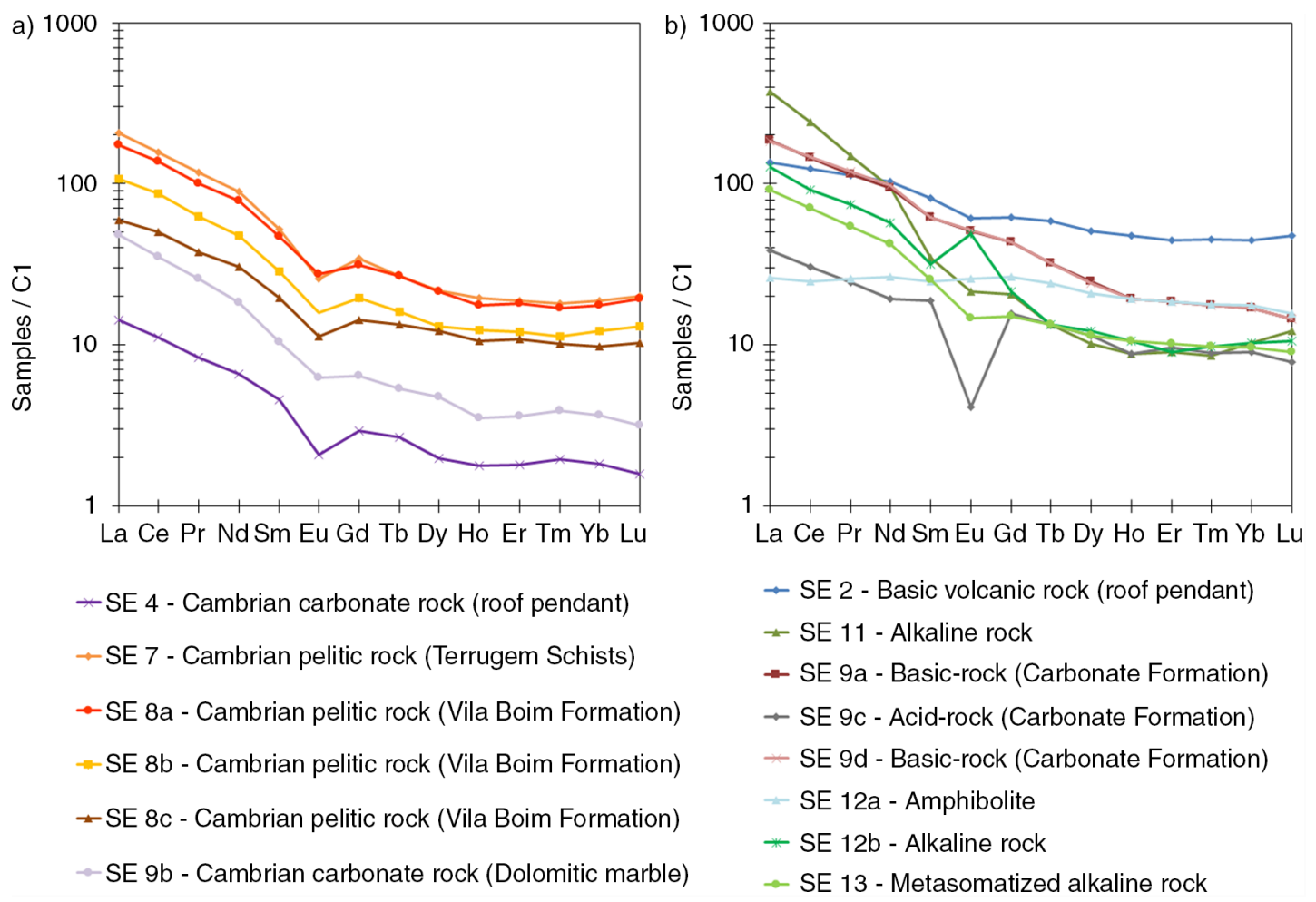

Fig. 3.-REE patterns of: (a) Metasedimentary rocks; (b) Meta-igneous rocks (C1 from Evenson et al., 1978). 
rocks (Fig. 2a) and by a slightly recristalization of the calcite of cabonate rock matrix. These features are well demonstrated in the samples SE 6a, SE 6b and SE $6 c$ collected very close to the ESE margin of the SEPC. The same evidence is present in the sample ASM 027, located in the western margin of the SEPC.

In the alkaline host rocks, intrusive in the metasedimentary rocks of the Série Negra, the igneous primary structure, texture and high-T minerals are preserved, namely the compositional banding typical of a primary magmatic differentiation. The petrographic features of the alkaline and metasomatized alkaline rocks and their geochemical composition point to the absence of thermal/metasomatization effects of the SEPC on these rocks. The metasomatization present in the sample SE 13 has resulted from the contact between the alkaline rock and the adjacente carbonate rock. The adjacent calc-silicate rocks present mineralogical composition consistent with thermal/metasomatic effets related to the alkaline rock intrusion. So, the lithologies of N and NE margins of the SEPC show thermal metamorphic textures, structural anisotropies and paragenesis, which are not related to the SEPC intrusion but to a previous magmatism.

On the other hand all the lithologies present in the roof pendants, namely pelitic, carbonate and basic volcanic rocks, exhibit a strong thermal effect, without metasomatic evidence. The occurrence of thermal effects restricted to the pluton roof may be caused by a combination of several interrelated factors: the volume ratio granite/host rocks is much higher in the roof pendants than in the surrounding host rocks, higher volume of granitic mass, thermal effect by advection of fluids, longer period of prevalence at elevated thermal conditions.

The previous very-low to low metamorphic grade of the host rocks of the SEPC, indicates an intrusion in a shallow and cold crustal level, and thus implying a thermal shock. However the absence of lateral thermal effects could be explained by quick cooling and the low volume ratio granite/rock wall.

\section{Conclusions}

The SEPC is a late-Variscan granitic body located in the northern part of the Ossa Morena Zone. The SEPC host rocks are composed of igneous, metaigneous, and metasedimentary units, from Upper
Proterozoic to Paleozoic ages, with a NW-SE structure. The SEPC host rocks, show very-low to high grade metamorphism. Those with very-low to low grade metamorphism present primary sedimentary or igneous mineralogical, textural and structural features well preserved. Both at east or at west, the host rocks comprise phyllite and quartz-phyllite, in chlorite zone conditions, without any thermal effects even at short metric distance from the contact.

The thermal effects of the SEPC intrusion on the igneous and meta-igneous rocks (granites, migmatites, gabbros, alkaline rocks, basic and acid volcanic rocks) are not evident, because the mineralogy and texture of these rocks are stable at high temperature. At $\mathrm{N}$ and NE of the SEPC, textures and paragenesis of high- $\mathrm{T}$ are not related to the SEPC intrusion but to a previous magmatism (Barquete granite and peralkaline rocks), controlled by the NW-SE regional anisotropies. These rocks show evidences of dynamo thermal metamorphism previous to SEPC.

The restriction of the thermal effects to the pluton roof may be caused by a combination of several interrelated factors: higher volume of granitic mass, thermal effect by advection of fluids, longer period of prevalence of high thermal conditions.

The geochemical study of the SEPC host rocks shows the heterogeneous character and diversity of metasedimentary, igneous and meta-igneous rocks. The whole rock geochemical data indicate that all the metasedimentary lithologies derived from an upper continental crustal source. The geochemical composition of the igneous and meta-igneous rocks do not show evidence of metasomatic effects by the SEPC emplacement.

These data suggest that the thermal effects of the SEPC in the host rocks are mostly restricted to the roof pendants.

\section{ACKNOWLEDGEMENTS}

This work has been financially supported by PTDC/CTEGIX/099447/2008 (FCT-Portugal, COMPETE/FEDER). The authors are grateful to Carlos Villaseca and Patrícia Moita whose comments greatly helped to improve the manuscript.

\section{References}

Araújo, A.; Piçarra Almeida, J.; Borrego, J.; Pedro, J. \& Oliveira, J.T. (2013). As regiões centro e sul da Zona de Ossa Morena. In: Geologia de Portugal, Volume 
I - Geologia Pré-mesozóica de Portugal (Dias, R.; Araújo, A.; Terrinha, P. \& Kullerberg, J.C., eds.). Escolar Editora, Lisboa, 509-549.

Evenson, N.M.; Hamilton, P.J. \& O’Nions, R.K. (1978). Rare earth abundances in chondrite meteorites. Geochimica et Cosmochimica Acta, 42: 1199-1212. http://dx.doi.org/10.1016/0016-7037(78)90114-X

Fonseca, P.; Munhá, J.; Pedro, J.; Rosas, F.; Moita, P.; Araújo, A. \& Leal, N. (1999). Variscan ophiolites and high-pressure metamorphism in Southern Iberia. Ofioliti, 24 (2): 259-268. http://dx.doi.org/10.4454/ ofioliti.v24i2.106

Gonçalves, F. (1971). Subscidios para o conhecimento geológico do Nordeste Alentejano. Memórias dos Serviços Geológicos de Portugal, 18 (Nova Série): 1-62.

Gonçalves, F. (1972) Carta Geológica de Portugal. 1:50000, Folha 33-C - Campo Maior. Serviços Geológicos de Portugal, Lisboa, 49 pp.

Gonçalves, F. (1975) Carta Geológica de Portugal. 1:50000, Folha 32-D - Sousel. Serviços Geológicos de Portugal, Lisboa, 49 pp.

Hoffman, E.L. (1992). Instrumental Neutron Activation in Geoanalysis. Journal of Geochemical Exploration, 44: 297-319. http://dx.doi.org/10.1016/0375-6742(92) 90053-B

Lopes, J.M.C.; Lopes, J.L. \& Lisboa, J.V. (1997). Caracterização petrográfica e estrutural dos granitos róseos do Complexo Plutónico de Monforte - Santa Eulália (NE-Alentejo, Portugal). Estudos, notas e trabalhos, Instituto Geológico e Mineiro, 39: 141-157.

Lopes, J.M.C.; Munhá, J.; Wu, C.T. \& Oliveira, V.M.J. (1998). O Complexo Plutónico de Monforte-Santa Eulália (Alentejo-NE, Portugal Central): caracterização geoquímica e considerações petrogenéticas. Comunicações do Instituto Geológico e Mineiro, 83: 127-142.

Menéndez, L.G.; Azor, A.; Pereira, M.D. \& Acosta, A. (2006). Petrogénesis de plutón de Santa Eulália (Alto Alentejo, Portugal). Revista de la Sociedad Geológica de España, 19 (1-2): 69-86.

Moita, P.; Munhá, J.; Fonseca, P.; Pedro, J.; Tassinari, C.; Araújo, A. \& Palácios, T. (2005). Phase equilibria and geochronology of Ossa-Morena eclogites. In: Actas IV Semana de Geoquímica - VIII Congresso de Geoquímica dos Países de Língua Portuguesa, 2: 471-474.
Oliveira, J.T.; Oliveira, V. \& Piçarra, J.M. (1991). Traços gerais da evolução tectono-estratigráfica da Zona de Ossa Morena, em Portugal. Cuadernos do Laboratorio Xeoloxico de Laxe, 16: 221-250.

Oliveira, J.T.; Pereira, E.; Ramalho, M.; Antunes, M.T. \& Monteiro, J.H. (1992). Carta Geológica de Portugal. 1:500000. Laboratório Nacional de Energia e Geologia.http:/geoportal.lneg.pt/arcgis/rest/services/ CGP500K/MapServer.

Pereira, M.F.; Chichorro, M.; Solá, A.R.; Silva, J.B.; Sánchez-García, T. \& Bellido, F. (2011). Tracing the Cadomian magmatism with detrital/inherited zircon ages by in-situ U-Pb SHRIMP geochronology (OssaMorena Zone, SW Iberian Massif). Lithos, 123: 204 217. http://dx.doi.org/10.1016/j.lithos.2010.11.008

Pereira, M.F.; Silva, J.B.; Solá, A.R. \& Chichorro, M. (2013). Nordeste Alentejano. In: Geologia de Portugal, Volume I- Geologia Pré-mesozóica de Portugal (Dias, R.; Araújo, A.; Terrinha, P. \& Kullerberg, J.C., eds.). Escolar Editora. Lisboa, 493-508.

Quesada, C.; Fonseca, P.; Munhá, J.; Oliveira, J. \& Ribeiro, A. (1994). The Beja-Acebuches Ophiolite (Southern Iberia Variscan Foldbelt): geological characterization and geodynamic significance. Boletín Geológico y Minero de España, 105 (1): 3-49.

Ribeiro, A.; Munhá, J.; Dias, R.; Mateus, A.; Pereira, E.; Ribeiro, L.; Fonseca, P.; Araújo, A.; Oliveira, T.; Romão, J.; Chaminé, H.; Coke, C. \& Pedros, J. (2007). Geodynamic evolution of the SW Europe Variscides. Tectonics, 26: TC6009. http://dx.doi. org/10.1029/2006TC002058

Ribeiro, A.; Munhá, J.; Fonseca, P.; Araújo, A.; Pedro, J.; Mateus, A.; Tassinari, C.; Machado, G. \& Jesus, A. (2010). Variscan ophiolite belts in the Ossa-Morena Zone (Southwest Iberia): Geological characterization and geodynamic significance. Gondwana Research, 17: 408-421. http://dx.doi.org/10.1016/j.gr.2009.09.005

Schermerhorn, L.J.G.; Priem, H.N.A.; Boelrijk, N.A.I.M.; Hebeda, E.H.; Verdurmen, E.A. \& Verschure, R.H. (1978). Age and Origin of the Messejana Dolerite Fault-Dike System (Portugal and Spain) in the Light of the Opening of the North Atlantic Ocean. Journal of Geology, 86 (3): 229-309. http://dx.doi. org/10.1086/649692 